\title{
As principais motivações para a migração internacional - o caso do Marrocos para a Espanha.
}

Aline Baú dos Santos*

\begin{abstract}
Resumo
Tendo como estudo de caso a migração de trabalhadores do Marrocos para Espanha, verificam-se dois importantes fatores que estimulam os trabalhadores à migração internacional: o econômico e o histórico. A premissa de que a economia é um dos principais motivadores à migração é amplamente divulgada e têm sido desenvolvidas diversas teorias a respeito, como, por exemplo, a Migration Hump, a Teoria Dual de Trabalho e a teoria Push and Pull, que têm determinantes econômicos em sua lógica. Essas teorias se enquadram na realidade migratória Magrebe-Espanha, contudo, a ciência econômica por si só não explica as motivações que os migrantes internacionais têm para escol herem um determinado país e correrem riscos de vida para habitá-lo. Questões simples como: "por que marroquinos arriscam a vida para viver na Europa" e "por que a maior densidade populacional de magrebinos que vão para a Espanha é do Ex-Protetorado Espanhol no Marrocos" passama ser melhor respondidas quando se alia ao estudo econômico a análise de conjuntura histórico social. Afinal, para a melhor compreensão da temática migratória internacional -inclusive suas motivações - observa-se a importância da perspectiva multidisciplinar que envolve a temática.

Palavras-chave: imigração internacional de trabalhadores, motivação à imigração, Marrocos - Espanha, teoria, história.
\end{abstract}

As principais motivações da emigração marroquina para a Espanha retratam dois importantes campos de estudo à migração internacional: o econômico e o histórico. Na esfera econômica observa-se o nexo entre desenvolvimento econômico e migração, nesse ínterim vislumbra-se teorias econômicas que encaixam-se na realidade marroquina: Migration Hump (Hass, 2008), Push and Pull (Ravenstein, 1889; Lee, 1966) e Teoria Dual do Trabalho (Jennissen, 2007). Por outro lado, pela perspectiva histórica, observa-se a importância da correlação dos laços históricos entre marroquinos e espanhóis ao nos depararmos com índices estatísticos que revelam as proporções das origens nacionais dos imigrantes (INE,2011). Nesse contexto, também se vislumbram paradigmas dos emigrantes que demonstram as consequências culturais da colonização

\footnotetext{
Mestre em Ciência Política pela Universidade Federal do Rio Grande do Sul. Email: alinebau3@hotmail.com.
} 
e as necessidades produzidas pelo capitalismo. Os fatores de motivação a emigração parecem mais fortes do que as barreiras impostas pela Espanha e União Europeia à imigração.

Confrontando mitos, estatísticas ${ }^{1}$ (ACP, 2012, versão online) indicam que os países que tem maiores índices de emigração não são os mais pobres. Essa assertiva encaixa-se nos recentes padrões de imigração da Espanha, que costuma ${ }^{2}$ receber potencialmente imigrantes das seguintes nacionalidades: marroquinos com 758.174 cidadãos residentes, seguidos de romenos (728.580), equatorianos (441.155), colombianos (288.255) e britânicos (221.073) (Tedesco, 2007). Da porção africana há destaque para a região magrebina, favorecida pela proximidade com o Mediterrâneo Europeu, com altos índices de emigração marroquina para Espanha. A Argélia e a Tunísia são dois países de intenso fluxo emigratório, porém, os dois têm uma presença marcante na França (Eurostat, 2010). Já na Espanha, suas comunidades são bastante reduzidas e não existe, portanto, toda a instrumentação institucional de que dispõem os Marroquinos.

Dessa forma, o presente trabalho focará o fenômeno migratório marroquino para Espanha que, além da importância do fenômeno traduzido em números brutos significativos de migração, demonstra a relevância do estudo econômico e histórico para a compreensão das motivações de trabalhadores a ultrapassarem barreiras sociais (preconceito, xenofobia), jurídicas (normativas restritivas aos imigrantes) e físicas (travessias perigosas e fronteiras cercadas, por exemplo) existentes no país receptor. Através de uma análise multidisciplinar, entre a perspectiva histórica e econômica, pode-se responder questionamentos simples como: Por que marroquinos arriscam a vida para viver na Europa? Por que a maior densidade populacional de magrebinos que vão para a Espanha são do Ex-Protetorado Espanhol no Marrocos?

\footnotetext{
${ }^{1}$ Estima-se que em todo o mundo há cerca de 214 milhões de migrantes internacionais (ONU, 2008). Contrariamente à percepção generalizada nos países desenvolvidos, só cerca de $40 \%$ dos migrantes internacionais se movimentam no sentido Sul-Norte. Ou seja, a maioria migra entre países em des envolvimento (ONU, 2010).

${ }^{2}$ Após 10 anos, em 2010 houve nova transformação nas taxas de emigração e na taxa de imigração nos países da OCDE. Devido à crise financeira do "subprime", houve um aumento da taxa emigratória (OCDE, 2010), que era de 0,99 por mil habitantes, entre 2003 e 2009, para 2,73 por mil habitantes em 2010 (Índex Mundi, 2011) e decréscimo da taxa de imigração. Porém, crises são transitórias, em contrapartida, a demanda europeia por imigração é de longo prazo (OCDE, 2011).
} 


\section{Motivação Econômica da Migração Marrocos-Espanha}

O aumento da imigração na Espanha coincide com o crescimento econômico espanhol, crescimento que também fora sentido por outros países do sul da Europa, como Itália e Portugal. Em 1975 inicia-se um novo ciclo na Espanha, caracterizado pela reconversão da estrutura produtiva da Espanha e penetração massiva de empresas transnacionais. Em 1985, o país obtém acesso às comunidades Europeias (entrada efetiva em janeiro de 1986), oferecendo maiores oportunidades aos imigrantes pela natureza e evolução específica do mercado: "informalidade, dualidade, flexibilidade, terceirização e o dinamismo da empreitada de menor escala" (King, 2003, p. 15).

Outras características auxiliaram a entrada dos imigrantes: Estímulo ao turismo, que beneficiava os chamados "residential tourists"; os poucos empecilhos à entrada imigratória (ao contrário dos seus vizinhos do norte que já haviam iniciado uma política de restrição desde a década de 70); a democratização iniciada em 1975, o histórico colonialista espanhol, que chamou a atenção da população ex-colonizada para a ex-metrópole e a proximidade com o continente africano, o que tornou a Espanha uma porta de entrada para imigrantes africanos, em especial vindos do Magrebe (Valiente, 2004, p. 232).

Em paralelo com o aumento da imigração, houve um crescimento impressionante do emprego. Entre 1994 e 2007, a Espanha (juntamente com a Irlanda) registrou a maior taxa de crescimento do emprego na Europa e o número de pessoas empregadas aumentou de 12 para 20 milhões (Comissão Europeia, 2007).

A maioria dos novos empregos foram absorvidos pelos setores de baixa qualificação, como a construção e os serviços gerais, onde a presença de trabalhadores imigrantes não qualificados é alta (Comissão Europeia, 2007). Segundo Bernardi et al (2011, p. 154), houve uma expansão na parte superior (grau universitário) e inferior (construção e setor de consumo) da escala ocupacional. Naquele período, os setores que exigiam maior qualificação educacional foram preenchidos pelos nacionais, sobrando, assim, uma abundância de oportunidades em empregos não qualificados na parte inferior da estrutura ocupacional. 
A nova fase econômica fez com que a Espanha passasse a não ser mero território de passagem, beneficiando os imigrantes econômicos. Pois com uma educação de qualidade e melhores oportunidades, os espanhóis deixaram lacunas no mercado de trabalho: serviços domésticos, agricultura, construção, setor industrial, turismo e buffets, venda informal (Ripoll, 2008, p. 30). Lacunas preenchidas por imigrantes que passaram a ser a mão de obra barata no país (Valiente, 2004, p. 232), aumentando a população ativa, auxiliando no crescimento financeiro de empresas, movimentando a economia informal e fomentando o desenvolvimento da Espanha (D'anol e Martinez, 2009, p. 287).

Pesquisas indicam que os principais países de emigração internacional em nível mundial não são os mais pobres, ao contrário, os emigrados advêm de países que estão em processo de desenvolvimento econômico e transformação social: México, Filipinas, China e Colômbia (Castles, 2008). Atualmente, grande parcela das emigrações internacionais caracteriza-se por uma mistura complexa e paradoxal de desenvolvimento e deficiências (CE, 2005, p. 57). De acordo com a Comissão Europeia (2002), a saída de contingente populacional de países em desenvolvimento ocorre, porque a satisfação das oportunidades no país de origem pode ser ainda limitada, na medida em que o processo de ajustamento e as reformas não estão terminados, e o mercado de trabalho interno ainda não atingiu o seu pleno potencial (CE,2002, p. 11).

No âmbito da União Europeia a imigração originária de países em desenvolvimento é expressiva. Segundo a Eurostat (2010), a maior proporção de não nacionais (36,5\%; 7,2 milhões de pessoas) advém de países europeus, com destaque para Turquia, Albânia e Ucrânia. O continente Africano representa o segundo maior contingente $(25,2 \%)$, desse, mais da metade vem do norte da África, especialmente Argélia e Marrocos. O terceiro contingente $(20,9 \%)$ com maior porcentagem na União Europeia é a Ásia, muitos da Índia e da China, como segue: 
Gráfico 1 - Imigração internacional na União Europeia: cidadãos dos Estados membrose não membros

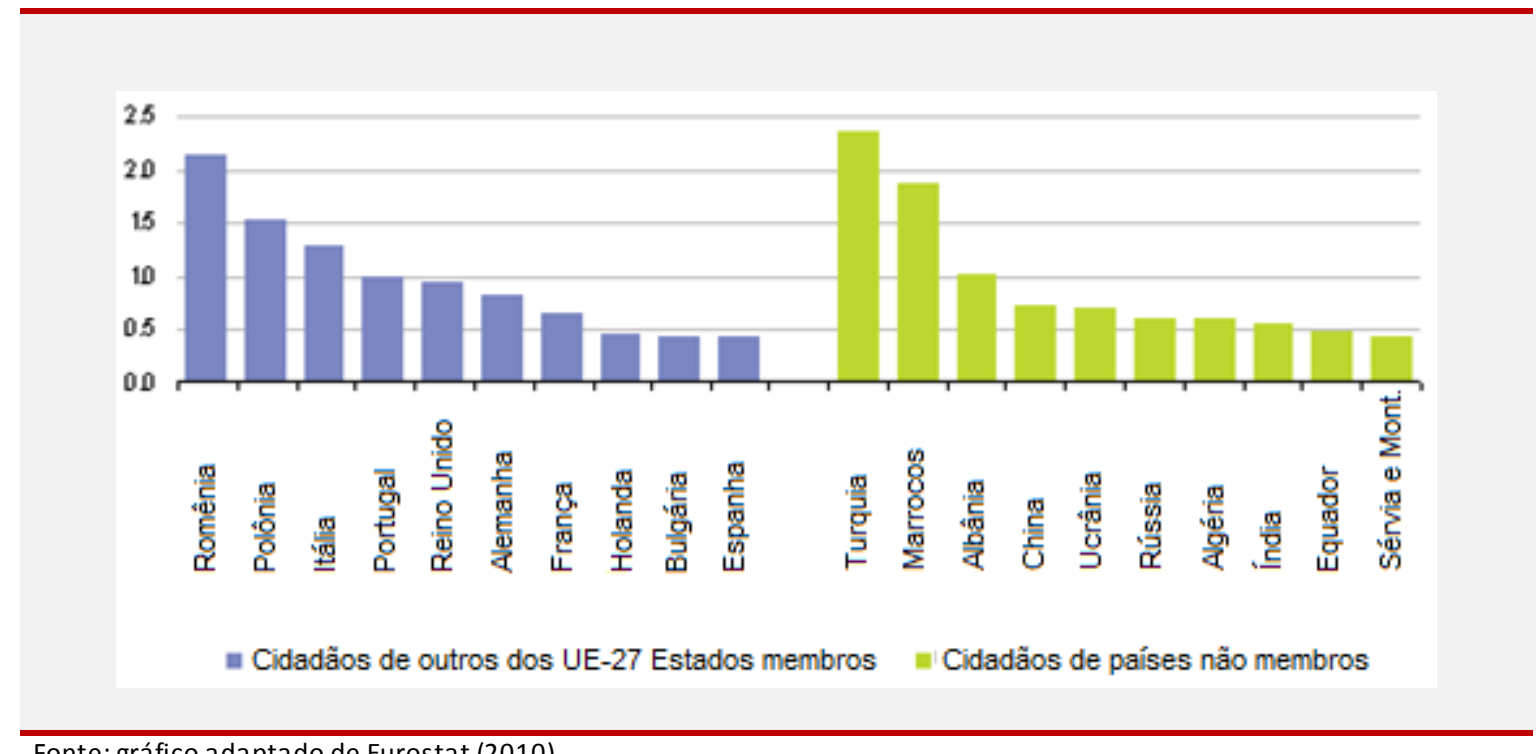

Fonte: gráfico adaptado de Eurostat (2010).

Na Espanha, grande parte dos fluxos imigratórios são oriundos da América Latina e Norte da África. É importante destacar que o ato de emigrar para outro país requer recursos financeiros ou acesso a redes sociais e capital social. Os custos para sair do território nacional não são acessíveis à maioria da população mundial, embora as viagens internacionais estejam mais baratas do que no passado. Assim, os mais pobres são uma parcela pequena da migração internacional, assim como as imigrações regionais e locais são mais abundantes. Bauman (1999) traduz essa realidade afirmando que a parcela realmente pobre da população mundial está fadada a ficar em casa, o direito de ser móvel não é aplicado à miséria - A pobreza em si não é razão suficiente aos altos contingentes emigratórios internacionais (CE, 2006, p. 57). A tendência emigratória dos países em processo de desenvolvimento pode ser explicada através do fenômeno migration hump (Hass, 2008, p. 16) e complementada através da lógica teórica do push-pull (Lee,1966; Castles 1997) e a teoria do mercado dual de trabalho (Jennissen, 2007).

O fenômeno migration hump consiste, basicamente, no argumento de que o país em processo inicial de desenvolvimento socioeconômico tende a elevar a capacidade e as aspirações das pessoas a emigrar, pois "nos países em desenvolvimento, empregos decentes não estão sendo criados rapidamente o 
suficiente para absorver o número crescente de pessoas que se juntam à força de trabalho a cada ano" (CE, 2005, p. 157). Os indicadores sociais e econômicos começam a evoluir, em contrapartida, o mercado de trabalho interno e o IDH ainda não atingiu seu pleno desenvolvimento (com reformas políticas e econômicas em andamento).

De acordo com o Conselho Europeu (2006), a principal força motriz das pressões migratórias contemporâneas é a falta de trabalho decente ${ }^{3}$ e oportunidades no país de origem. Apesar do Marrocos, da Argélia e da Tunísia disporem de importantes recursos naturais, esses países não conseguem criar emprego suficiente, "exportando não apenas recursos naturais como também pessoas" (Leal, 2009, p. 7).

A economia do Estado marroquino é dominada pelo setor agrícola. Marrocos produz pequenas quantidades de petróleo e gás natural, centrando-se na extração de fosfatos no Saara Ocidental. O vestuário e outros produtos têxteis assumem uma importância relevante no comércio exterior marroquino, quase um terço do total exportado. Também são importantes as reservas de pesca que em geral são exploradas por frotas estrangeiras (Marrocos, 2012; Leal 2009, p. 5).

Embora existam muitas motivações individuais para a decisão de emigrar, as pessoas motivam-se a buscar novas oportunidades de emprego, renda e qualidade de vida em países desenvolvidos:

\begin{abstract}
A situação dos agricultores nos países em desenvolvimento é um importante fator internacional de migração. Muitos países industrializados tiveram uma "grande emigração" em 1950 e 1960, e movimentos semelhantes são hoje evidentes em muitos países, incluindo China, México e Turquia. Isto é, em parte, o resultado de, entre outros fatores, políticas públicas que muitas vezes refletem pacotes de ajustamento estrutural que levaram os países a "Modernizarem" a produção agrícola para se tornarem mais orientados para a exportação, e, consequentemente, minar a posição dos pequenos agricultores através da crescente liberalização do comércio (CE, 2006, p. 56).
\end{abstract}

Há outros problemas estruturais que contribuíram para a emigração nos países em desenvolvimento: a importação de produtos baratos prejudicou setores da

\footnotetext{
3 A expressão "trabalho decente", utilizada no presente trabalho, refere-se aos direitos que a OIT defende serem fundamentais aos trabalhadores: (i) liberdade sindical e reconhecimento efetivo do direito de negociação coletiva; (ii) eliminação de todas as formas de trabalho forçado; (iii) abolição efetiva do trabalho infantil; (iv) eliminação de todas as formas de discriminação em matéria de emprego e ocupação, a promoção do emprego produtivo e de qualidade, a extensão da proteção social e o fortalecimento do diálogo social (OIT, 1998).
} 
indústria doméstica e da produção agrícola, o que afetou diretamente diversos setores da economia, ocasionando a perda de posto de trabalho, pois a criação de empregos pelos Programas de Ajustamento Estrutural ${ }^{4}$ foi inferior ao desemprego. Assim, a consequência de perdas de emprego resultante de mudanças comerciais e estruturais parece ter aumentado o número de desempregados. Na ausência de oportunidades de trabalho, a emigração torna-se uma alternativa para aqueles que têm mínimas condições de realizar uma viagem internacional (CE, p. 58, 2006).

Quando o processo de desenvolvimento começa satisfazer as necessidades econômicas e sociais da população, há redução da emigração internacional. Esse cenário pode ser representado em um gráfico por um " $U$ " invertido: em um processo de desenvolvimento socioeconômico a emigração vai aumentando até um determinado nível que começa a diminuir no momento em que o país começa a satisfazer os anseios da sociedade (Hass, p. 17, 1996). Nesse sentido, vê-se o papel da escolha individual à migração. Os imigrantes são seres racionais que fogem para regiões favoráveis, onde as suas necessidades de uma vida segura ou de uma vida melhor podem ser atendidas (CE, 2006 p. 158).

A teoria Push-Pull, elaborada antes do conceito de migration hump, com sua premissa de efeitos de expulsão e atração, é bem colocada na realidade de migração internacional e complementa o efeito de migration hump. Apesar da teoria Push-Pull apontar o subdesenvolvimento como um fator à emigração (de Ravenstein - 1889, refinada por Lee em 1966) e na obra de Lee (1966) apresentar muitas condições de push-pull irreais à atualidade migratória internacional, a Teoria trouxe o princípio que há variáveis que empurram determinado grupo de pessoas e, em contrapartida, variáveis em outros países que as atraem. Os obstáculos (sociais, econômicos, físicos, etc) à imigração serão analisados pelos emigrantes de acordo com a relação custobenefício.

Assim, segundo a teoria de Lee (1966):

\footnotetext{
${ }^{4}$ Os Programas de ajustamento Estrutural foram preconizados pelo Banco Mundial e o Fundo Monetário Internacional a partir dos anos 1980 como condições para que países em desenvolvimento pudessem aderir empréstimos junto às instituições. Os Programas de Ajustamento Estrutural consistiam na aplicação de privatizações e na liberalização da economia; visavam conduzir a alteração das relações laborais e o papel do Estado como agente de desenvolvimento (Kingston, et al; 2011, pág. 110).
} 
Tabela 1 - Síntese da teotia de Lee, 1966

Efeito Push - emigração (LEE, 1966)

\section{Fatores socioeconômicos}

Oferta insuficiente de emprego

Renda baixa, condições ruins de habitação

Altos impostos e taxas / Setor público precário

Pobreza / Distribuição desigual da riqueza

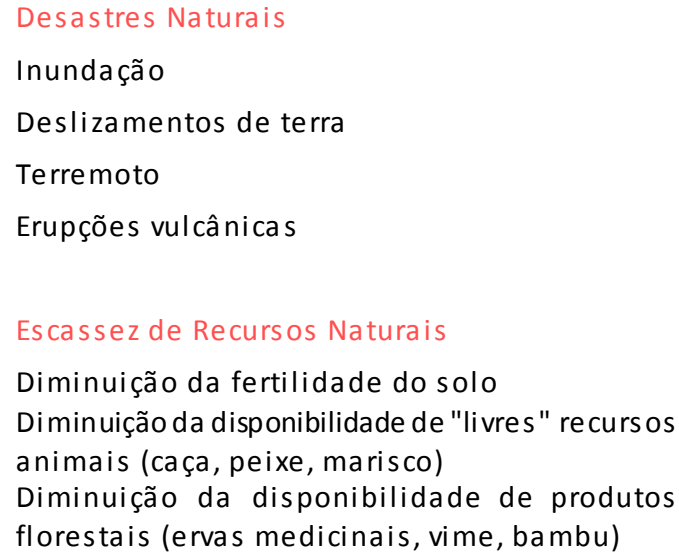

Fonte: Lee (1966)

Ao analisar a Teoria Dual para a migração completamos as motivações básicas para a decisão de emigrar: falta de oportunidades no país de origem, oferta de trabalho no país de destino. Como se observou na Espanha, e anteriormente em outros países europeus, há um nível de expansão econômica em que os nacionais não estão mais dispostos a trabalhar em baixas posições hierárquicas (mesmo que estivessem dispostos, a escassez de mão de obra em um setor poderia ser transferida a outro). A
Fatores socioeconômicos

Muitas ofertas de emprego/setores informais da cidade (acesso fácil para os imigrantes ilegais) Renda maisalta/boa moradia, especialmente na relação familiar existente

Funcionamento do sistema de saúde/segurança Boa s oportunidades educacionais/ampla gama de serviços, oportunidades culturais e recreativas

Problemas demográficos

Oferta de terra suficiente

A mudança demográfica causou escassez de mão de obra/planejamento estruturado

\section{Política}

Leis de imigração fa voráveis

Possibilidade de imigração ilegal

Reconhecimento dos imigrantes como um potencial de inova ção

Segurança jurídica 
alternativa é recrutar imigrantes econômicos que veem as oportunidades em setores econômicos secundários de baixo prestígio como a possibilidade de inserirem-se e se posicionarem-se no mercado estrangeiro. Além disso, a carência inicial de trabalho disponível no país receptor pode empurrar os salários para cima, fazendo com que a migração seja ainda mais atraente. A população imigrante torna-se, assim, importante para empresas e uma alternativa para grupos sociais de estrangeiros insatisfeitos com a realidade de seu país de origem (Jennissen, 2007).

Ao serem analisadas as teorias acima descritas e a realidade migratória da União Europeia, mais precisamente da Espanha, verificam-se os pontos de expulsão (-) e atração (+) da migração de países em desenvolvimento para os desenvolvidos. E, também, os obstáculos a serem ponderados pelos potenciais emigrantes.

Pode-se assim formular o seguinte modelo:

\section{Figura 1 - Efeito "push and pull" e obstáculos a serem ponderados- estudo de caso}

Empecilhos

Possibilidade de sofrer sanções do governo do país receptor; risco de rechaço pela sociedade receptora; marginalização social devido ao status de irregularidade; punições da União Europeia- detenção, risco de violência etc.; fronteiras monitoradas e policiadas; risco na viagem por meios irregulares; restrição jurídica à imigração econômica ; afastamento do ambiente de origem- família, cultura, etc.

\footnotetext{
Fonte: elaboração própria.
}

Com o desemprego e um Estado que não consegue suprir as necessidades de 
sua população, o governo marroquino encara a emigração como uma estratégia para o desenvolvimento - solução para o desemprego, para a balança de pagamentos e um mecanismo para aprimorar o conhecimento e as competências de seus nacionais - na espera que eles retornem (Leal, 2009, p. 8).

\section{Contexto Histórico Marrocos - Espanha}

Ao analisarmos a imigração na Espanha verificamos que maior parte dos imigrantes advém de países em desenvolvimento, o que nos remete ao estudo da área econômica; assim como de países que eram colônias da Espanha; o que nos remete ao estudo da História. Os latino-americanos representam o maior índice de imigrantes internacionais na Espanha e os marroquinos (que têm o facilitador da proximidade geográfica com a Espanha e foi um ex-protetorado espanhol) por sua vez, estão em primeiro lugar quando analisada a nacionalidade dos imigrantes, 758.174 cidadãos marroquinos residentes (Tedesco, 2007).

Assim, o contexto histórico também é importante e fundamental para o entendimento das migrações internacionais. Demonstra as continuidades e descontinuidades dos processos migratórios e explica outros fatores que dão substrato às motivações a emigrar. No contexto Magrebe e Mediterrâneo Europeu, a história remonta séculos de relações entre essas regiões o que repercute na aproximação cultural, nas políticas de imigração, nos fluxos migratórios e na paixão ou rechaço a terras estrangeiras.

O fluxo de pessoas entre Marrocos e Espanha remonta ao século VIII ao século $\mathrm{XV}$, quando das conquistas árabes na Europa. Com a expulsão dos árabes do continente Europeu, houve um fluxo massivo de populações em direção ao Magrebe, incluído o Marrocos. Ainda no século XIX, houve mais um fluxo migratório espanhol em direção ao país, sendo ali criadas diversas comunidades espanholas.

Ainda antes da independência em 1956, o Marrocos já apresentava um refluxo migratório, com cerca de 500.000 habitantes migrando em direção à Espanha e França. Estes, contudo, eram, em esmagadora maioria, naturais de seus países que para lá retornavam. Já na década de 1960, começava um significativo fluxo emigratório 
marroquino direcionado à Europa. A Espanha, por outro lado, ainda não oferecia muitos atrativos a esses emigrantes. Nas décadas seguintes começa um grande movimento direcionado à Espanha, iniciando, na década de 1970, na Catalunha e nos países bascos. Esse movimento se estabelece, como rota principal, somente na década de 1990, em virtude da queda do atrativo das migrações dirigidas à França e Itália (Bilgili; Weyel, p. 7-13, 2009).

Essa transição de rota migratória foi possível devido à Espanha estar, no início da década de 1990, em plena expansão econômica, situar-se a 15 km do território espanhol e conter facilidades decorrentes, além das necessidades econômicas por mão de obra barata dos anos em que fora país de emigração e das relações políticoeconômicas entre Marrocos e Espanha que resultaram, respectivamente, em pequenas facilidades na lei de imigração espanhola e ao deslumbre cultural marroquino pela Espanha - porta de entrada aos símbolos e imaginários ocidentais.

Não se pode ignorar a influência de uma dominação política e econômica entre países. As províncias ao norte do Marrocos foram protetorado espanhol de 1912 até 1956, além de consequências econômicas ambientais houve consequências culturais. Ainda hoje, pode-se ver os resquícios da arquitetura espanhola em cidades marroquinas - referenciais simbólicos do antigo império espanhol e a relação entre os povos - marroquinos passaram a conhecer o idioma e a cultura espanhola. A informação advinda da Espanha passou a ser mais fluída e interessante ao povo marroquino e intensificada através de meios de comunicação e empresas de telecomunicação espanholas. No norte do Marrocos, a maioria dos cafés de cidades como Tánger, Tetuán apresentam-se lotados de pessoas assistindo series, programas, propagandas e filmes oriundos da Espanha (Gavira, 2008, p. 173).

Assim devido a fatores econômicos e históricos, não é de se estranhar que a maioria dos emigrantes marroquinos que partiram para a Espanha após 1990 sejam naturais das províncias do norte do Marrocos (Tánger, Tetuán, Alhucemas, Chauen, Nador y Larache) (Gavira, pág. 178, 2008). Afinal, durante três séculos, os territórios vulneráveis ao mundo ocidental foram divididos e explorados à manutenção do sistema de acumulação de capital (Arrighi, 2006). Após as independências coloniais, os países foram neocolonizados ( $N^{\prime}$ Krumah, 1967). A viagem realizada pelos excolonizados vem aferir uma herança colonial: a imigração internacional realizada pelos 
conquistados, muitas vezes fluxos indesejados pelos países receptores.

Apesar dos benefícios da imigração internacional para os países europeus (auxílio à previdência privada, mão de obra, mercado consumidor alternativo aos nacionais $^{5}$ etc.) e para os países de emigração (remessas financeiras, $8 \%$ do PIB Marroquino, auxílio ao desenvolvimento econômico local) (Pais e Morgado, 2010, p. 2), tem-se visto uma política restritiva e coercitiva aos imigrantes advindos de países em desenvolvimento e pouco qualificados (IOÉ, 2008, p. 4). A França e a Inglaterra, antigos países de imigração na Europa, por exemplo, desde a década de 1970 tem empregado duras normativas de imigração a fim de conter a tendência imigratória (Mahlke, 2005, p. 92; Focus Migration, 2005, p. 6). Martinello (2005) divide em três fases o posicionamento ${ }^{6}$ do continente europeu diante da imigração até os anos 2000: A primeira fase, de 1950 a 1973, de estímulo à imigração; a segunda, de 1973 a 1980, de restrição à imigração e da construção da ideia de imigração como problema a ser securitizado; e a terceira, de 1980 a 2000, da securitização da imigração, principalmente da imigração clandestina.

Espanha, ao contrário da Europa Ocidental mais ao Norte, era país de emigração no pós-guerra e tinha que buscar aceitação e integração em outros países europeus. Essa trajetória diferenciada representa um indício do porquê das primeiras normativas à imigração representarem uma política imigratória liberal. Contudo, essa liberalidade era relativa: Também na Espanha havia restrição por motivos societários, xenofobia e racismo (ONU, 2001). Em análise comparativa com outros países europeus, entretanto, era ainda liberalidade (Hammar, 1985).

\footnotetext{
${ }^{5} \mathrm{Na}$ Espanha, por exemplo, o setor financeiro tem direcionado produtos e campanhas publicitárias aos clientes mais recentes do setor: os imigrantes (regulares ou não). Isso tem gerado uma nova economia étnica que emprega imigrantes e nativos, o que representa uma expressão líquida de produção e emprego.

${ }^{6}$ Segundo Catherine Withtol (2009, p. 25), as grandes etapas que marcaram as restrições da União Europeia são constituídas de dez normativas que abordam de forma direta ou indireta a imigração: Os acordos de Schengen (1985), a Assinatura dos Acordos de Dublin sobre asilo (Dublin I em 1990 e Dublin II em 2003), o art. $8^{\circ}$ do Tratado de Maastricht(1992), a Declaração de Barcelona (1995), a modificação do Tratado de Amsterdam (1997), o Conselho Europeu de Tampere (1999), o Livro Verde Europeu (2005), o Pós Cúpula de Hampton Court - Reino Unido (2005), a Diretiva de Retorno (2008), os cinco compromissos do Pacto Europeu sobre imigração e asilo (2008).
} 
Quando analisadas a criação e as reformas ${ }^{7}$ da "Ley de Extranjeria" verifica-se o impacto do ingresso da Espanha na Comunidade Europeia em 1985 e na formalização dos acordos de Schegen. O território espanhol era visto pelos membros da então Comunidade Europeia como uma fronteira liberalizada, risco a toda Europa ocidental. Portanto, Exigiu- se da Espanha o fortalecimento das normativas internas à imigração internacional como cumprimento das medidas compensatórias presentes nos acordos firmados. A consequência da dualidade, entre a necessidade de imigrantes para o desenvolvimento econômico espanhol e das imposições de outros países europeus a uma política restritiva, foi uma política imigratória a partir de 1985 marcada pela ênfase a integração, à legalização à regulação, à restrição e controle de imigrantes.

A lei espanhola por vezes beneficiou os marroquinos, como por exemplo, na primeira versão da Lei de Extranjeria que de modo dual demonstrou a iniciativa da Espanha em harmonizar as suas normativas com as preocupações da então Comunidade Europeia, e, assim, demarcar fronteiras jurídicas à migração euromediterrânea. Em junho de 1985, a Espanha aderiu à Comunidade Europeia e, em 1991, assinou o Acordo de Schengen com mais cinco países (Bélgica, França, Alemanha, Luxemburgo e Holanda). Assim, a Lei Orgânica 7/85 entrou em vigor no dia primeiro de julho de 1985.

Em contrapartida às restrições impostas ao imigrante, a Ley de Extranjeria beneficiou alguns grupos de imigrantes. Estrangeiros de Portugal, Filipinas, América Latina, Guiné Equatorial e judeus sefarditas não eram obrigados a apresentar visto e receberam preferência na obtenção de permissão de residência e trabalho. Assim como os imigrantes advindos do Marrocos, Tunísia e Argélia receberam a isenção da obrigação de obter um visto (Espanha, 1985, art. 23). O privilégio dado aos magrebinos, peruanos e dominicanos foi revogado em 1991, o que produziu em extenso número de ilegais, ano em que a Espanha aderiu à Convenção de Schengen. Mas, em 1992, a Espanha regulariza ${ }^{8}$, através de um acordo com o Marrocos, os ilegais

\footnotetext{
7 Leis orgânicas 4/2000, 8/2000, 14/2003 y 2/2009, 557/2011 (Ministério del Interior, 2012, versão online).

${ }^{8}$ Como tentativa de se inserirem na sociedade espanhola, os Marroquinos, junto com Argentinos, são os imigrantes que mais adquiriram a nacionalidade Espanhola desde 1985 (MTAS, 2004). Entretanto, a alteração de status jurídico não significa que exista uma maior aceitabilidade por parte do povo Espanhol, que continua a estereotipar o Marroquino como estrangeiro.
} 
marroquinos residentes no território espanhol, atitude tomada em razão das políticas pesqueiras e de agricultura que eram negociadas no âmbito da União Europeia e importantes à Espanha (Mazkiaran, 2004).

No ano 2000, com a presença de significativo número de imigrantes marroquinos regulares e irregulares, a lei 8/2000 abriu caminho à assinatura de acordos bilaterais com os principais países que originam os fluxos imigratórios na Espanha Equador, Colômbia, Marrocos, República Dominicana, Nigéria, Polônia, Romênia e Nigéria. Com exceção do acordo com a Nigéria, os acordos negociavam o acesso à entrada no território e ao mercado de trabalho espanhol. Em 2003, os dois governos acordam sobre a construção de postos de acolhimento para o repatriamento de menores desacompanhados. Esse acordo previa o respeito aos direitos dos jovens e a adoção de medidas para o resgate do convívio social desses indivíduos. O texto versava sobre medidas de acompanhamento econômico e medidas socioeducativas baseadas em um sistema de financiamento para os interessados (CARIM/AS 2006/9, p. 14).

Esses acordos regulam as oportunidades de trabalho e, como tal, preveem a comunicação de ofertas de emprego, a avaliação dos profissionais, requisitos de viagem e recepção. Eles também corroboram para melhorar os direitos laborais e sociais dos trabalhadores imigrantes. Além disso, foram realizadas disposições de acordos especiais para os trabalhadores sazonais e medidas para facilitar seu retorno a seus países de origem (Arango, 2003, versão online). De acordo com Cebola e Requeira:

\begin{abstract}
La migración marroquí hacia España es hoy el vínculo más importante entre dos países que se han entendido más bien poco a lo largo de la historia (Hernando, 2005; López Bueno, 2004). Con todo, no se puede ignorar que incluso aunque las relaciones hispano marroquíes sean hoy mucho más intensas que hace unos años, tienden a padecer períodos recurrentes de tensión, generada en parte por disputas migratorias. Las desavenencias en torno a los movimientos migratorios han estado siempre muy presentes en la agenda bilateral de ambos países, tanto por la condición de Marruecos de país emisor como por la de escala de quienes emigran desde los países subsaharianos (Hernando, 2005). (Cebola e Héctor Miguel Requena, 2010 p. $5-6)$.
\end{abstract}

Apesar dos ânimos estatais expostos entre país de emigração e imigração em discursos e normativas à formulação de acordos que promovam benefícios bilaterais e 
o respeito aos Direitos Humanos, há incoerência entre a realidade e o desenvolvimento de acordos e políticas que respeitem a integridade do migrante internacional. Vê-se que as restrições migratórias aos clandestinos passaram a ser um fenômeno global no âmbito Magrebe/União Europeia, pois a pressão desse continente àquela região suscitou um constante diálogo entre as duas partes, confundindo o tratamento migratório com políticas securitizadoras, feitas sob a justificação do terrorismo devidos a casos como o 11 de setembro (Estados Unidos, 2001), 11 de março (Espanha, 2004) e os atentados à Casa Blanca (Marrocos, 2007). Em função dessas prerrogativas, Marrocos e Espanha institucionalizaram uma série de medidas visando o controle de suas fronteiras, desde comitês locais de fiscalização e estruturação ao reforço do policiamento fronteiriço, à criação de um observatório, composto por membros de diversos ministérios, responsáveis pelo controle estatístico dos índices de emigração irregular (Ministère de La Justice Marocaine, 2003). Em diálogo com a Espanha, essas instituições agregaram a responsabilidade pela luta à xenofobia expressa em folhetos eleitorais naquele país.

Entretanto, dentro do imaginário midiático, os Marroquinos representam o estereótipo característico do imigrante africano, chamados de "Los moros", eles são os imigrantes mais rechaçados pelo povo Espanhol. Mesmo que a imigração Marroquina seja a mais densa e mais antiga na Espanha, sua inserção na comunidade espanhola é bastante problemática, eles são os mais pobres $^{9}$ e os mais marginalizados entre a população estrangeira na Espanha (Romero e Fernandez, 2004). A situação é ainda pior aos imigrantes marroquinos que vivem em situação irregular, os quais não possuem auxílio-desemprego, educação gratuita e auxílio residência (ASEP/IMSERSO, 2000).

A hostilidade dos espanhóis aos marroquinos era visível na segunda metade do século XIX e nas primeiras do século XX. As autoridades espanholas não pouparam esforços para consolidar a imagem do marroquino traidor, sanguinário e selvagem com o objetivo de maior apoio da opinião pública às ações militares (Guerra de Tetouan, em 1859) contra Marrocos e, assim, mobilizar jovens para as missões. Além, com a reapropriação do Saara Ocidental pelo Marrocos e as tensões políticas advindas da

\footnotetext{
${ }^{9}$ Em consequência da imigração em massa na Espanha ser um fenômeno novo, ainda não há como confiar em redes étnicas pré-existentes que possam auxiliar os novos imigrantes, situação complicada ainda mais pelo alto número de imigrantes irregulares (Bernardi et al ,2011, p. 151).
} 
significativa imigração marroquina fizeram com que o preconceito continuasse a imperar. Isso se reflete no vernáculo espanhol com expressões estereotipadas que revelam a rivalidade antiga e o atual preconceito que se agravam em períodos de crise econômica (Real Instituto Alcano, 2012)

Assim, ainda que existam parcerias entre o governo do Marrocos e da Espanha em matéria de migração clandestina (Bartolomeu, 2009, p. 3), os emigrantes Marroquinos são constantemente rechaçados pelas autoridades hispânicas, uma visível afronta aos acordos assinados entre os dois países. De acordo com o relatório de população estrangeira na Espanha, realizado pelo Instituto Nacional de Estatística da Espanha, os Marroquinos são a maior população detida entre todos os imigrantes.

O controle de detenção de imigrantes ilegais, no estreito de Gibraltar, é demonstrado na tabela abaixo, de acordo com a região de detenção:

\section{Tabela 2 - Imigrantes detidos no Estreito de Gibraltar em 2004}

\begin{tabular}{lrrr}
\hline & 2004 & 2005 & Va riação \\
Il has Canárias & 8426 & 4715 & -3711 \\
Almeria & 2241 & 1853 & -388 \\
Granada & 2745 & 2678 & -67 \\
Málaga & 686 & 748 & 62 \\
Cádiz & 1295 & 1375 & 80 \\
Ceuta & 268 & 224 & -44 \\
Melila & 8 & 188 & 180 \\
Murcia & 2 & 0 & -2 \\
Ibiza & 4 & 0 & -4 \\
Total zona do estreito & 7249 & 7066 & -183 \\
Total nacional & 15675 & 11781 & -3894 \\
\hline
\end{tabular}

Fonte: Secretaria de Estado à Imigração e Emigração, Es panha

Em 2009, Uma nota interna de uma delegacia da capital espanhola, divulgada pelo sindicato dos policiais nos meios de comunicação, revela que os agentes espanhóis tinham ordem para prender uma cota mínima de imigrantes ilegais na Espanha. A nota não define apenas quantidade, mas também nacionalidade, e prioriza a detenção de marroquinos, em detrimento de bolivianos, por ser mais barato repatriá-Ios (Opera Mundi, 2009). 


\section{Manobras dos imigrantes marroquinos}

A presença das dificuldades de inserção no território espanhol não restringiu os fluxos migratórios. Inclusive, há transição demográfica e transformação nos padrões de migração no Marrocos. O país é emissor, destino e ponto de passagem de migrantes que se dirigem para Espanha e para a Europa. O Rei Hassan II disse uma vez que "Marrocos era uma árvore com raízes em África e os ramos na Europa" (apud Leal, 2009, p. 36).

Apesar do rígido controle de fronteiras e das medidas punitivas direcionadas ao imigrante irregular, a União Europeia contou com índices expressivos de residentes irregulares $^{10}$, cerca de 4,5 milhões de pessoas (Comissão Europeia, 2007, p. 7). Segundo o relatório da Comissão Mundial sobre Migrações Internacionais (GCIM) de 2005, o continente é porta de entrada para 560 mil imigrantes ilegais todos os anos. Desses, estima-se que dois mil africanos morrem ao tentar atravessar o Mediterrâneo.

O contingente de 4,5 milhões de residentes ilegais parece irrisório se comparado aos 18,5 milhões de imigrantes regularizados até o ano de 2007 (C.E., 2007, p. 7). Contudo, os riscos assumidos ao entrar no território por via irregular são grandes (com frequência são noticiados acidentes) e os preços cobrados para realizar a travessia são altos, em 2007, o custo era em torno de 1.000 Euros $^{11}$ para migrar do Norte da África para a Europa (ONU, 2007). Além dos riscos da travessia, muitos dos irregulares, ao se instalarem no território, passam a viver à margem da sociedade.

Os Marroquinos que atentam adentrar o território Espanhol utilizam de diversos meios, e aqueles que entram de forma irregular são os que mais sofrem com a falta de segurança e insalubridade na travessia. Fenômeno denominado de "Pateras", esses percursos não se restringem a um só trajeto, passam por diversos acessos, tendo como padrão a travessia noturna, partindo da costa Marroquina situada entre Tanger e o enclave Espanhol de Ceuta, adentrando a costa de Cádiz, pelo setor das Algesiras

\footnotetext{
10 Segundo Castles (2010, p. 2), a expressão “imigração ilegal” vem conferir a condição de criminoso ao imigrante que não adquiriu a documentação exigida pelas autoridades. O teórico sustenta que descumprir normas administrativas não faz de um ser humano ilegal. A PICUM-Platform for International Cooperation on Undocumented Migrants (2007, p. 2), defende que o termo "imigração ilegal" não existe no Direito Internacional e definir um indivíduo ou um grupo como "ilegal" pode ser considerado como uma forma de não reconhecimento da sua natureza humana, correndo-se o risco de violar o seu direito de ser reconhecido como pessoa perante a lei.

${ }^{11}$ Segundo o Lejuste Salaire (2010), a média salarial dos marroquinos era de 943 Euros em 1997.
} 
(Arango, 2008).

Para acessar o país Espanhol, os imigrantes podem percorrer, principalmente, o Estreito de Gibraltar, o enclave de Ceuta e Melila e as ilhas Canárias. Defrontando-se com diversos mecanismos adotados pelo governo espanhol, os atravessadores do Mediterrâneo alteram sistematicamente as rotas de passagem, tornando, por vezes, o caminho mais longo e utilizando de embarcações comerciais como forma de burlar a vigilância Estatal. Com o reforço dos meios de policiamento, também modernizam-se os meios de transporte e o grau de institucionalização das máfias que promovem a imigração ilegal de Marroquinos (UNODC, 2011, p. 32)

Há uma relevante mobilidade das embarcações irregulares, que conseguem burlar a vigilância da Guarda Civil Espanhola, utilizando-se de telefones móveis para obter atualização de rotas e pontos de encontro com os receptores localizados já na Espanha, isso tudo ainda durante o período de travessia. Por outro lado, nem sempre a travessia se dá com meios exclusivos de transporte para emigrantes ou em barcos comerciais, alguns Marroquinos são levados à Espanha com a obtenção de documentos falsos, estando inseridos na população Espanhola que sai do Marrocos, ou com propósito oficial de turismo.

Outra rota de imigração, as Ilhas Canárias, começaram com um fluxo intenso em 1994, quando africanos saarianos buscavam acesso a Forteventura e Lanzarote como refugiados políticos. Como se abria uma nova rota de acesso à Espanha, começou um grande fluxo de "Pateras" àquela região (UNODC, 2011). Para burlar os esquemas de segurança do governo Espanhol, são verificados casos de corrupção das autoridades hispânicas responsáveis, além do envolvimento de setores do governo Marroquino, que facilitam a obtenção de documentos de viagem e outras formas de ajuda aos emigrantes ilegais (OIM, 2011). Não bastasse isso, a intensidade e forma de controle marroquinos sobre esses eventos transforma-se de acordo com a situação das relações entre os dois países. 


\section{Conclusão}

Teorias econômicas de imigração internacional e o contexto histórico têm relevância à compreensão da migração internacional. O poder da influência de fatores econômicos e históricos é observado quando as dificuldades advindas de políticas restritivas e de empecilhos à integração na sociedade receptora não reprimem o fenômeno imigratório. Sob a perspectiva econômica observamos teorias como: Migration Hump (Hass, 2008), Push and Pull (Ravenstein, 1889; Lee, 1966) e Teoria Dual do Trabalho (Jennissen, 2007) atuando nas motivações de emigrar. Em paralelo, há questões históricas que influenciam, no caso Marrocos-Espanha, afinal, não se pode desconsiderar as consequências históricas de séculos de relações entre países na temática migratória internacional. Se por um lado, a história política e econômica das relações entre os países estudados geraram consequências negativas no trato com o imigrante marroquino no país receptor, por outro gerou uma agenda política entre os dois países que tem como base a migração internacional - que ora gerou benefícios aos imigrantes marroquinos, ora os prejudicou - e a aproximação do marroquino, principalmente os que se encontram no ex-protetorado espanhol, com a cultura espanhola.

A Espanha recebe em maior número imigrantes advindos de ex-colônias. No caso da migração Marrocos-Espanha, verifica-se maior número de marroquinos (em primeiro lugar entre os nacionais imigrantes) advindos do ex-protetorado espanhol. Observa-se no caso estudado, que as motivações dos trabalhadores migrantes podem ser explicadas através de teorias econômicas, contudo a eleição do país a ser imigrado advém também do contexto histórico que une essas pessoas ao país de destino, contexto que pode alimentar o imaginário do migrante - independente dos horizontes concretos das relações sociais que se apresentam (Tedesco, 2007, p. 9).

Nesse cenário, Boswell (2011, p. 6) afirma que há dificuldade do Estado em orientar comportamentos imigratórios geridos através da subsistência e das expectativas de obter melhor qualidade de vida. As sanções típicas usadas pelo Estado a outras áreas do comportamento individual como: estratégias de comando da lei e as formas tradicionais de regulamentos apoiada por imposição hierárquica de sanções não tendem a alcançar os resultados desejados, assim como as formas de coerção e 
controle de fronteiras. Iniciativas como essas apenas incentivam o imigrante a burlar a lei e a fiscalização (Botwell, p. 16, 2011). Assim, enquanto as políticas imigratórias não tornam-se eficazes, a migração internacional de trabalhadores (Marrocos - Espanha) continuará tendo como um de seus resultados mortes e prisões

\section{Referências bibliográficas}

ACP. 2012. "Observatório ACP das Migrações". Disponível em: <http://www.acpmigrationobs.org/pt-pt/node/1096 >. Acesso em 02 de março de 2012.

Arango, Joaquin. 2003. "Dificultades y dilemas de las políticas de inmigración", Circunstancia. Revista de Ciencias Sociales del IUIOG, Madrid, Espanha.

Arango, Joaquín; Jachimowicz, Maia. 2008. Regularizing Immigrants in Spain: A New Approach. Washington: Migration Policy Institute. Disponível em: <http://www.williamperezphd.com/articles/arango-jachimowicz-2005.pdf>. Acesso em: 18 nov. 2011.

Bartolomeu et al. 2009. CARIM - Consortium for Applied Research on International Migration. Disponível em: <http://www.carim.org/public/migrationprofiles/MP_Morocco_EN.pdf> Acesso em: 15nov. 2011.

Bauman, Zygmunt. 2008. Vida para consumo. Rio de Haneiro Zahar.

Bauman, Zygmunt. 1999. Globalização. Rio de Janeiro: Zahar.

Bernardi F et al. IOM. 2011. The Recent Fast Upsurge of Immigrants in Spain and Their Employment Patterns and Occupational Attainment. Disponível em: <http://onlinelibr ary.wiley.com/doi/10.1111/j.1468-2435.2010.00610.x/pdf>. Acesso em: 13 ago. 2011.

Bezunartea, Patricia; López, José; Tedesco, Laura. 2009. "Muslims in Spain and Islamic Religious." MICROCON Policy Working Paper 8.

Bilgili, Özge; Weyel, Silja. 2009. Migration in Morocco: History, Current Trends and Future Prospects.Maastricht Graduate School of Governance. Disponível em: <http://mgsog.merit.unu.edu/ISacademie/docs/CR_morocco.pdf>. Acesso em 15 nov. 2010.

Boswell, Christina. 2011. "Immigration Control and Narratives of Steering." The British Journal of Politics \& International Relations. V. 13, pp. 12-25.

Castles, Stephen; MILLER, Mark J. 2008. Age of Migration. The international population movements in the Modern. Eua: The Guilford.

Cebolla, Héctor; Requena, Miguel. 2010. Marroquíes en España, los Países Bajos y Francia: gestión de la diversidad e integración. Real Instituno Elcano. Disponível em: <http://www.realinstitutoelcano.org/wps/portal/rielcano/contenido?WCM_GLOBAL_CONT EXT=/elcano/elcano_es/zonas_es/demografia+y+poblacion/dt11-2010 > Acesso em: 27 dez. 2011. 
Colectivo loé. 2008. Dimensiones de la inmigración en España: Impactos y desafíos. Disponível em:

<http://www.colectivoioe.org/uploads/aba56be3f5fa1a1d2abef464a521a82b69ee4f85.pdf>. Acesso em: 16 jul. 2011.

Comissão Europeia. 2006. Relatório Geral sobre a Atividade da União Europeia. Luxemburgo.

Comissão Europeia. 2005. Relatório Geral sobre a Atividade da União Europeia. Luxemburgo.

Comissão Europeia. 2002. Comissão ao Conselho e ao Parlamento Europeu: integrar as questões ligadas à Migração nas Relações da União Europeia com Países Terceiros, COM. Bruxelas.

Eurostat (Org.). 2008. Recent migration trends: citizens of EU-27 Member States become ever more mobile while EU remains attractive to non-EU citizens. Issue number 98/2008. Disponível em: <http://epp.eurostat.ec.europa.eu>. Acesso em: 15 fev. 2011.

Focus Migration. 2007. Reino Unido. Disponível em: <http://focusmigration. hwwi.de/index. php?id=2708\&L=1>. Acesso em: 12 nov. 2011

Gavira, Gabriel. 2008. "Inmigrantes Marroquíes em España: Permanencia o Retorno." Entelequia - Revista Interdisciplinar, no 8, out. 2008. Disponível em: <http://www.eumed.net/entelequia/p df/2008/e08a13.pdf. Acesso em: 25 nov. 2011.

GCIM - Global Commission On Internactional Migration. Migration in an interconnected world: New directions for action. 2005. Disponível em: <http://www.queensu.ca/samp/migrationresources/reports/gcim-complete-report-2005. pdf >. Acesso em: 10 out. 2010.

Haas, Hein. Migration and development: a theoretical perspective, 2008. Disponível em: <http: //www.heindehaas.com/workingpapers.htm1>Acesso em: 15 out. 2011.

Hammar, Tomas. 1985. Política Europeia de Imigração: Um Estudo Comparativo. Cambridge University Press.

King, R. e Ruiz-Gelices, E. "International student migration and the European 'Year Abroad': effects on European identity and subsequent migration behavior", International Journal of Population Geography, 9(3): 229-252, 2003.

Kingston (et al). "The Impacts of the World Bank and IMF Structural Adjustment Programmes on Africa: The Case Study of Cote D'Ivoire, Senegal, Uganda, and Zimbabwe." Sacha Journal of Policy and Strategic Studies, Vol. 1, No. 2, pp. 110-130, 2011.

Lee, Everett. “A Theory of Migration.” Demography, v. 3, n. 1, pág. 47-57, 1966.

Le Jus Salarie. http://www.lejustesalaire.com/salaire-par-pays/salaires-maroc.php. Acesso em: 02 de fev. 2013.

Mahlke, Elisane. 2005. O Estado Nação e a migração internacional de Trabalhadores. $140 \mathrm{f}$. Dissertassão (mestrado) - Universidade Federal do Rio Grande do Sul, Curso de Pós Graduação em Relações Internacionais.

Marrocos. 2013. "Site oficial nacional do Marrocos." <www.maroc.ma/Portaillnst/An/>Acesso em: 02 de fev. 2013. 
N'krumah, Kwame. 1967. Neocolonialismo: Último Estágio do Imperialismo. Civilização Brasileira.

OCDE. 2011. Migration in the Post-Crisis World. França: Oecd Publishing, 2011. Disponível em: <http://www.oecdbookshop.org.> Acesso em: 1 nov. 2011.

ONU. 1998. Declaração da OIT sobre os princípios e direitos fundamentais no trabalho e seu seguimento, OIT. Disponível em: <http://www.oitbrasil.org.br/sites/default/files/topic/international_labour_standards/pub/dec laracao_direitos_fundamentais_294.pdf >.Acesso em: 20 mar. 2011.

ONU. 2011. Conferência Mundial Contra o Racismo, Discriminação Racial, Xenofobia e Intolerância. Organização Internacional do Trabalho (OIT) e Organização Internacional para as Migrações. (OIM). Disponível em: < http://www.unhcr.org/refworld/pdfid/49353b4d2.pdf>. Acesso em: 15/10/2012.

Pais, Rita e Morgado, Mariana. 2010. Imigração, Integração e Diversidade. Que respostas europeias? IEEI- Instituto de Estudos Estratégicos e Internacionais. Disponível em: http://www.ieei.pt/files/Integracao_Diversidade.pdf . Acesso em: 20 set. 2011.

Ripoll, Erika Masanet. 2008. "O Brasil e a Espanha na dinâmica das migrações internacionais: um breve panorama da situação dos emigrantes brasileiros na Espanha." Rev. bras. estud. popul. vol. 25, n.1, pp. 151-165.

Tedesco, João Carlos. 2010. Estrangeiros, Extracomunitários e Transnacionais:Paradoxos da alteridade nas migrações internacionais. Porto Alegre: Pontifícia Universidade Católica do Rio Grande do Sul.

Tedesco, João Carlos. 2007. Fios que tecem o processo migratório internacional: trabalhadores brasileiros na Itália. V Encontro Nacional sobre Migrações. Universidade Federal de Passo Fundo-RS. Disponível em: <http://www.abep.nepo.unicamp.br/docs/anais/outros/5EncNac SobreMigracao/public_fio_tec_pro.pdf > Acesso em: 27 de fev. 2011.

Unodc. 2011. The role of organized crime in the smuggling of migrants from West Africa to the European Union, ONU. Disponível em: <http://www.unodc.org/documents/humantrafficking/Migrant-Smuggling/Report_SOMWest_Africa_EU.pdf> . Acesso em dez. 2011.

Valiente, Juan. 2004. "Migraciones". VVAA, Tendencias demográficas durante el siglo XX en España. Madrid, INE, pp. 207- 253. 